Kapata Arkeologi, 13(2), 195-208

ISSN (cetak): 1858-4101

ISSN (elektronik): 2503-0876

http://kapata-arkeologi.kemdikbud.go.id

\title{
KAWASAN KOMPLEKS BANGUNAN MEGALITIK DI KABUPATEN LAHAT SEBAGAI DAYA TARIK WISATA BUDAYA DAN ALAM
}

\section{Megalithic Building Complex Zone In The District Lahat Attraction As A Cultural And Natural}

Ni Komang Ayu Astiti

Kementerian Pariwisata - Indonesia

Jl. Medan Merdeka Barat No. 17 Jakarta 10110

astitiayu69@yahoo.co.id

Naskah diterima: 28/08/2017; direvisi: 17/10—17/11/2017; disetujui: 17/11/2017

Publikasi elektronik: 30/11/2017

\begin{abstract}
The contribution of tourism to the global economic development continues to increase, affecting the government's policy to make tourism one of the priority sectors of national development after food and maritime. This becomes an opportunity to explore creatively the potential to fill this opportunity. The main question in this research is focus on how the complex area of megalithic building can play an important role in as a resource in national development, especially in the economic sector through tourism. The objective of the study is to restore megalithic complexes from the archaeological context to the social context of today's society as a resource in the development of contemporary times while maintaining its preservation. The method used a qualitative descriptive approach with data collection techniques through direct observation and interview. The results show that this cultural heritage can be a tourism commodity produces products that provide experience in: 1) important historical value; 2) the value of information; 3) aesthetic value; and 4) symbolic value. Strategies used in the management of integrating cultural heritage and the natural environment (landscape), enhancing the role of communities and other stakeholders, maintaining the originality and authenticity of megalithic and landscape buildings, and fostering the desire to invest and community effort. This management is expected to use a conservation approach to cultural and environmental resources as well as community empowerment.
\end{abstract}

Keywords: megalithic building complex, tourist attraction, management

Abstrak

Kontribusi pariwisata dalam pembangunan ekonomi secara global terus meningkat, berdampak pada kebijakan pemerintah untuk menjadikan pariwisata sebagai salah satu sektor prioritas pembangunan nasional setelah pangan dan maritim. Hal ini menjadi peluang mengekplorasi secara kreatif potensi yang ada. Permasalahan penelitian dalam tulisan ini adalah bagaimana kawasan kompleks bangunan megalitik dapat berperan penting sebagai sumber daya pembangunan nasional khususnya dalam sektor ekonomi melalui kepariwisataan. Tujuan penelitian tulisan ini untuk mengembalikan kompleks bangunan megalitik dari konteks arkeologi ke konteks sosial masyarakat sekarang sebagai sumber daya dalam pembangunan masa kekinian dengan tetap menjaga pelestariannya. Metode penelitian menggunakan pendekatan kualitatif deskriftif dengan teknik pengumpulan data melalui observasi langsung dan wawancara. Hasil penelitian menunjukan bahwa warisan budaya ini dapat menjadi komoditas pariwisata yang menghasilkan produk yang memberikan pengalaman (experiences) dalam: 1) nilai penting sejarah; 2) nilai informasi; 3) nilai estetika; dan 4) nilai simbolik. Strategi yang digunakan dalam pengelolaan yaitu memadukan warisan budaya dan lingkungan alam, meningkatkan peran masyarakat dan pemangku kepentingan lainnya, mempertahankan originalitas dan otentisitas bangunan megalitik dan lansekap, serta menumbuhkan keinginan untuk berinvestasi dan usaha masyarakat. Pengelolaan ini diharapkan menggunakan pendekatan pelestarian sumber daya budaya dan lingkungan serta pemberdayaan masyarakat.

Kata kunci: kompleks bangunan megalitik, daya tarik wisata, pengelolaan 


\section{PENDAHULUAN}

Pariwisata telah memberikan kontribusi yang besar dalam pembangunan ekonomi baik secara nasional maupun global. Pada tahun 2004 sektor pariwisata mencapai kondisi tertinggi sepanjang sejarah yaitu sebesar 763 juta orang, dan uang yang dikeluarkan oleh wisatawan sebesar US\$ 623 miliar. Kondisi ini meningkat $11 \%$ dari jumlah perjalanan tahun 2003 yang mencapai 690 juta orang dengan jumlah pengeluaran wisatawan US\$ 524 miliar. Jumlah perjalanan wisata dunia di tahun 2020 diperkirakanakan menembus angka 1,6 miliar orang per tahun (United Nation - World Tourism Organization, 2005; Utama, 2011: 1). Indonesia memanfaatkan peluang ini dengan menjadikan pariwisata sebagai sektor prioritas ekonomi nasional setelah pangan dan maritim dengan menargetkan jumlah kunjungan wisatawan mancanegara sebanyak 20 juta orang, pergerakan wisatawan Nusantara 275 juta orang, dan PDB 480 triliun rupiah pada tahun 2019. Indonesia kaya akan potensi sumber daya sebagai aset untuk pengembangan dan pencapaian target kunjungan wisatawan baik alam, budaya maupun daya tarik buatan yang tersebar di seluruh Nusantara.

Kabupaten Lahat merupakan salah satu kabupaten di Provinsi Sumatera Selatan yang mempunyai alam dan warisan budaya potensial sebagai aset dalam pembangunan pariwisata. Warisan budaya diartikan sebagai produk atau hasil budaya fisik dari tradisi-tradisi yang berbeda dan prestasi spiritual dalam bentuk nilai dari masa lalu yang menjadi elemen pokok dalam jati diri suatu kelompok atau bangsa (Davidson, 1997: 2). Ditemukan kompleks bangunan megalitik di kabupaten Lahat yang merupakan produk atau hasil budaya fisik masyarakat dari masa prasejarah atau budaya megalitik berupa dolmen, menhir, arca-arca megalitik dan bilik batu/kubur batu (Astiti, 2012: 1). Kompleks bangunan megalitik ini sebagian besar ditemukan di bentang lahan perbukitan yang saat ini sudah banyak dimanfaatkan sebagai areal pertanian, yaitu sawah dan kebun. Keunikan budaya megalitik dalam lansekap yang alami tentunya menjadi daya tarik bagi wisatawan untuk mendapatkan pengalaman dan pengetahuan yang baru. Daya tarik atau atraksi wisata adalah segala sesuatu yang dapat menarik wisatawan untuk berkunjung pada suatu daerah tujuan wisata baik alam, budaya, maupun atraksi buatan (Yoeti, 2002: 5).
Kawasan bangunan megalitik merupakan salah satu sumber daya alam yang dapat dikembangkan sebagai daya tarik wisata alam selain a). keajaiban dan keindahan alam (topografi); b). keragaman flora; c). keragaman fauna; d). kehidupan satwa liar; e). vegetasi alam; f). ekosistem yang belum terjamah manusia; g). rekreasi perairan (danau, sungai, air terjun, pantai); h). lintas alam (trekking, rafting, dan lainlain); i) suhu dan kelembaban udara yang nyaman; j) curah hujan yang normal, dan lain sebagainya (Damanik \& Weber, 2006: 2). Kompleks bangunan megalitik merupakan tinggalan arkeologi yang dapat memberikan pengetahuan dan tingkah laku manusia pada masa lalu. Warisan budaya ini dapat memberikan catatan sistematis yang menguraikan aktivitas manusia masa lalu, sehingga dapat membantu untuk mengerti tingkah laku manusia tidak hanya dimasa lampau, tetapi juga di masa sekarang (Crowther, 1991: 37). Penggunaan kebudayaan materi untuk mempelajari manusia dalam lingkungan budaya, sosial dan ekonominya sepanjang waktu, arkeologi melihat pada keseluruhan huniannya atau tata ruangnya (Kingery, 1996: 41). Dengan demikian pengelolaan kompleks bangunan megalitik di Kabupatan Lahat sebagai daya tarik wisata juga dapat memberikan pengetahuan tentang budaya dan perilaku masyarakat pendukungnya pada masa itu kepada wisatawan. Hal ini artinya kawasan bangunan megalitik sebagai daya tarik wisata merupakan sebuah komoditas pariwisata karena pada kebudayaan materi didalamnya terkandung nilai experiences.

Warisan budaya sebagai komoditas pariwisata juga mempunyai makna kekinian yang potensial dikembangkan untuk kepentingan ideologis. Dalam era globalisasi, jati diri atau identitas daerah sangat penting dimiliki yang membedakan dengan daerah lain untuk menghindari budaya yang cenderung homogen. Pengelolaan potensi kompleks bangunan megalitik dengan lansekap di sekitarnya sebagai komoditas pariwisata merupakan eksplorasi kreatif. Dapat mengenali potensi daerah dan memunculkan karakter atraksi wisata yang khas daerah dan mencirikan budaya lokal tentunya menambah keunikan dan daya tarik wisata di daerah Lahat. Memunculkan berbagai nilai dan budaya yang terkandung pada setiap bangunan megalitik di setiap atraksi wisata dapat menjaga keberlanjutan industri pariwisata secara nasional. Pengelolaan secara optimal komplek kawasan 
bangunan megalitik sebagai warisan budaya mempunyai peluang selain untuk kepentingan pariwisata juga pelestarian sumber daya tersebut. Pengelolaan merupakan upaya terpadu untuk melindungi, mengembangkan, dan memanfaatkan cagar budaya melalui kebijakan perencanaan, pelaksanaan, dan pengawasan. Dengan demikian pengelolaan pada dasarnya merupakan aspek manajemen dari pelestarian dengan tujuan agar memberikan manfaat bagi kesejahteraan rakyat. Pengelolaan kompleks bangunan megalitik di Kabupaten Lahat untuk kepentingan ekonomi melalui kepariwisataan sangat penting dilakukan untuk memunculkan nilai dan makna kekinian terutama untuk kesejahteraan masyarakat. Kompleks bangunan megalitik merupakan situs arkeologi sehingga pengelolaan dalam industri pariwisata harus menerapkan konsep-konsep pelestarian. Sumber daya ini mempunyai sifat terbatas, mudah rapuh dan tidak dapat diperbaharui sehingga pengelolaannya dalam industri pariwisata harus tepat. Suatu daerah dijadikan sebagai lokasi permukiman tentunya berdasarkan pertimbangan tertentu seperti faktor lingkungan geografis yaitu letak yang strategis dan terjaga keamanannya terutama dari faktor lingkungan, seperti banjir dan binatang buas serta ketersediaan sumber daya alam. Dalam konteks kekinian, kondisi ini tentunya dapat dijadikan sebagai daya tarik wisata untuk kepentingan ekonomi maupun sosial budaya sekaligus meningkatkan pelestarian warisan budaya dan alam sesuai slogan pariwisata "semakin dimanfaatkan semakin terlestarikan.”

Pembangunan pariwisata secara global sangat mempengaruhi perkembangan di segala sektor baik ekonomi, sosial budaya, politik maupun pembangunan infrastuktur. Pada bidang sosial budaya, setiap daerah harus memunculkan karakter daerah sesuai dengan potensi yang dimiliki. Pesatnya pembangunan ini juga mempengaruhi perubahan tata ruang termasuk keberadaan situs-situs arkeologi terutama yang berada dekat dengan permukiman atau daerah industri. Kompleks bangunan megalitik di Kabupaten Lahat sebagian besar berada di daerah perbukitan yang sudah dimanfaatkan sebagai permukiman dan pertanian. Dalam tata ruang pembangunan daerah ini perlu penanganan khusus dalam pengelolaan agar tidak menghilangkan nilai dan makna warisan budaya. Tata ruang yang salah atau mengganti bangunan lama dengan bangunan yang baru dalam konteks kekinian dapat menghilangkan atau mengurangi keberadaan warisan budaya baik secara fisik maupun experiences berupa keunikan dan keotentikannya. Pada pembangunan ekonomi di era globalisasi, warisan budaya yang termasuk sumber daya arkeologi banyak dijadikan komoditas bernilai ekonomis melalui industri pariwisata.

Dalam menghindari eksploitasi warisan budaya sebagai produk pariwisata dan dianggap sebuah barang atau jasa, dalam industri pariwisata perlu strategi pengelolaan yang tepat. Pengelolaan kompleks bangunan megalitik sebagai atraksi wisata di Kabupaten Lahat dapat dilakukan dengan mengoptimalkan nilai intangible yang dimiliki. Sumber daya arkeologi mempunyai nilai informatif, simbolik, estetik dan ekonomik (Lipe, 1989: 9). Nilai dan makna simbolik dapat ditunjukan karena sumber daya arkeologi merupakan bukti nyata yang dapat menghubungkan masyarakat sekarang dengan masa lalu yaitu jaman atau masa sumber daya ini dibuat. Sumber daya ini merupakan media atau simbol yang dapat membantu ingatan masyarakat tentang masa lalu, meskipun tidak semua aspek dan nilai budaya terekam pada sumber daya ini. Keberadaan kompleks bangunan megalitik di Kabupaten Lahat dapat memberikan informasi tentang masa pembuatan, teknologi, fungsi, keindahan, dan perilaku masyarakat pedukung budaya ini.

Besarnya nilai yang terkandung dan banyaknya kepentingan terhadap warisan budaya termasuk kompleks bangunan megalitik di Kabupaten Lahat, menimbulkan berbagai konflik kepentingan. Konflik kepentingan dan pluralisme yang berkembang dalam masyarakat juga menimbulkan wacana baru dalam visi pelestarian. Banyak pihak memahami dan mengarahkan bahwa pelestarian merupakan upaya mengarahkan warisan budaya untuk "tidak mengubah" atau "mengembalikan ke keadaannya semula," pelestarian yang dilakukan adalah hanya untuk warisan budaya itu sendiri. Konsep ini tentunya tidak dapat diterapkan pada bangunan megalitik di Kabupaten Lahat, termasuk yang ditemukan di daerah-daerah lain karena tidak dapat memberikan kontribusi pada sistem masyarakat sekarang. Meskipun bangunan megalitik mempunyai sifat-sifat yang sama dengan warisan budaya lainnya, yaitu tak terbaharui (non-renewable), terbatas (finite), mudah rapuh, dan bersifat khas (contextual), 
dengan pengelolaan yang bijaksana dapat dimanfaatkan dalam konteks kekinian. Pelestarian dapat dilakukan dengan upaya untuk mempertahankan nilainya sekaligus mengaktualkannya ke dalam konteks sistem masyarakat sekarang. Dengan demikian pelestarian harus dapat mengakomodasi dinamika dan perubahan yang berkembang di masyarakat. Keberadaan sumber daya budaya ada dalam dua konteks, yaitu masih berperan aktif dan dipergunakan dalam sistem masyarakat seharihari (seperti banyak ditemukan pada system masyarakat di Bali) dan sumber daya yang tidak dipergunakan lagi dalam sistem kehidupan masyarakat sehari-hari seperti yang ditemukan di Kabupaten Lahat.

Kompleks bangunan megalitik di Kabupaten Lahat merupakan salah satu sumber daya budaya, sehingga untuk menjaga pelestariannya harus tetap berada pada konteks kekinian yaitu berperan penting dalam pembangunan nasional. Pada pembangunan di sektor ekonomi, warisan budaya dapat menjadi daya tarik wisata khususnya di atraksi wisata budaya. Tujuan penelitian ini adalah mengembalikan kompleks bangunan megalitik dari konteks arkeologi ke konteks sosial masyarakat saat ini, sehingga berguna bagi kehidupan masyarakat sekarang dan tetap terjaga pelestariannya. Pemanfaatan warisan budaya sebagai daya tarik wisata merupakan upaya untuk memberikan makna baru yang berbeda dengan makna masyarakat pendukungnya di masa lalu. Makna baru ini selain untuk kepentingan ekonomi melalui kepariwisataan juga sebagai identitas atau jati diri masyarakat di Kabupaten Lahat, Provinsi Sumatra Selatan.

Daerah Lahat sebagai daerah pertanian dan masyarakatnya yang mayoritas mempunyai keahlian dalam mengeola lahan pertanian sudah dimiliki sejak masa megalitik. Hal ini ditunjukkan dengan temuan kompleks bangunan megalitik di lingkungan dataran tinggi Pasemah. Masyarakat pendukung budaya megalitik pada masa itu telah menunjukkan kemampuan di bidang agraris yang cukup maju. Masyarakat agraris dengan lingkungan yang sangat asri dapat dikembangkan sebagai daya tarik wisata tersendiri selain wisata budaya. Akivitas masyarakat dalam mengolah lahan dan hasil-hasil pertanian menjadi salah satu atraksi wisata yang mulai banyak diminati oleh wisatawan mancanegara.

\section{METODE}

Kompleks bangunan megalitik di Kabupaten Lahat dengan lansekap dataran tinggi Pasemah yang sudah dimanfaatkan sebagai daerah pertanian dan permukiman, dapat dikelola sebagai daya tarik wisata budaya dan alam. Kompleks ini harus dikelola secara bijaksana, agar dapat memberikan makna kekinian bagi masyarakat sekarang, baik secara ekonomi maupun ideologi. Metode yang digunakan untuk menjawab permasalahan penelitian yaitu: 1) Pengumpulan data dilakukan dengan pendekatan deskriptif-kualitatif dengan: a). Studi pustaka (hard data), untuk data sekunder diperoleh dari hasil-hasil penelitian terdahulu yang telah dipublikasikan, baik dalam bentuk artikel, buku, maupun laporan penelitian yang mendukung untuk menjawab permasalahan dalam tulisan ini; b). Melakukan observasi langsung (soft data) yang dilakukan pada beberapa kompleks bangunan megalitik di Kabupaten Lahat; dan c). melakukan wawancara dengan stakeholder dan wisatawan yang berkunjung ke kompleks bangunan megalitik; 2) Melakukan analisis deskriptif kualitatif dengan teknik SWOT, yaitu melakukan deskripsi faktor-faktor internal dan eksternal yang berpengaruh dalam pengelolaan kompleks bangunan megalitik di Kabupaten Lahat sebagai destinasi wisata budaya dan alam. Analisis SWOT dapat dibagi menjadi dua kategori, yaitu faktor-faktor internal dan eksternal. Faktor internal terdiri dari strengths (kekuatan) dan weaknesses (kelemahan), sedangkan faktor eksternal mencakup opportunities (peluang) dan threats (ancaman) dari masyarakat atau pemangku kepentingan lainnya.

\section{HASIL DAN PEMBAHASAN}

Pengembangan Kawasan Megalitik sebagai Daya Tarik Pariwisata Budaya dan Alam

Kawasan bangunan megalitik yang ada di Kabupaten Lahat dapat dikembangkan menjadi komoditas industri pariwisata dengan perencanaan dan pengelolaan yang tepat sehingga menjadi daya tarik pariwisata khususnya wisata budaya. Wisata budaya adalah suatu perjalanan yang dilakukan atas dasar keinginan untuk memperluas pandangan hidup sesorang dengan jalan mengadakan kunjungan atau peninjauan ke tempat lain atau ke luar negeri, mempeljari keadaan rakyat, kebiasaan dan adat istiadat mereka (Pendit, 1986: 36). Pariwisata budaya 
adalah sebuah industri yang dapat direncanakan, dikontrol, dan mempunyai tujuan untuk menghasilkan produk serta dapat dipasarkan (Christou, 2005; Utama, 2011: 2). Komoditas pariwisata di kawasan megalitik bertujuan menghasilkan produk berupa experiences dari nilai dan makna budaya yang dikandung pada setiap bangunan megalitik serta dapat dipasarkan sebagai daya tarik wisata. Pariwisata budaya juga dapat berupa perpaduan dua industri, dimana warisan budaya yang berperan untuk merubah sebuah lokasi menjadi destinasi dan pariwisata merupakan aktivitas ekonomi (KirschenblattGimblett, 1998: 151; Utama, 2011: 4). Konsep ini dapat diterapkan dalam pengembangan kawasan bangunan megalitik dengan menjadikannya sebagai destinasi wisata. Kawasan megalitik sebagai destinasi wisata menyebabkan banyak terjadi aktivitas pariwisata dan secara langsung meningkatkan aktivitas ekonomi masyarakat. Upaya-upaya pengelolaam seluruh potensi yang ada baik sumber daya budaya maupun lingkungan alam (lansekap) sebagai destinasi perlu dikembangkan untuk meningkatkan aktivitas ekonomi baik secara lokal maupun global. Eksplorasi kreatif untuk mengenali potensi kompleks bangunan megalitik dengan lansekap di sekitarnya merupakan upaya mengembangkan dan memperkaya khasanah daya tarik wisata di Sumatra Selatan. Daya tarik wisata berdasarkan Undang-undang RI No. 10 tahun 2009 tentang kepariwisataan, pasal 1 ayat 5 menyatakan bahwa daya tarik wisata adalah segala sesuatu yang memiliki keunikan, keindahan, dan nilai yang berupa keanekaragaman kekayaan alam, budaya dan hasil buatan manusia yang menjadi sasaran atau tujuan kunjungan wisatawan. Tingkat keanekaragaman daya tarik wisata penting artinya untuk kelangsungan industri pariwisata baik skala lokal maupun nasional (Undang-undang RI, 2009).

Pengembangan kawasan megalitik sebagai daya tarik wisata merupakan salah satu usaha untuk meningkatkan jumlah keragaman daya tarik wisata yang ditawarkan di Sumatra Selatan. Keragaman atraksi wisata pada suatu daerah akan memberikan peluang untuk meningkatkan kunjungan wisatawan sehingga memaksa mereka untuk tinggal lebih lama di destinasi wisata. Daya tarik pariwisata dapat berkembang di suatu daerah pada dasarnya karena destinasi tersebut mempunyai daya tarik, baik karena keunikan maupun keindahnnya. Daya tarik ini dapat menjadi motivasi yang mendorong wisatawan untuk berkunjung ke kawasan megalitik. Attractionare the on-location places in region that not only provide the things for tourist to see and do but also offer the lure to travel (Gunn, 1998: 48). Daya tarik dapat dibagi menjadi tiga kategori, yaitu a) natural attraction, yang berdasarkan pada bentukan lingkungan alami diantaranya iklim, pemandangan, flora dan fauna serta keunikan alam lainnya; b) cultural attraction yaitu berdasarkan pada aktivitas manusia mencakup sejarah, arkeologi, religi, dan kehidupan tradisional; dan c) special types of attraction yaitu atraksi yang tidak berhubungan dengan kedua kategori di atas, tetapi merupakan atraksi buatan seperti theme park, circus, shopping (Inskeep, 1991: 77). Potensi pengembangan daya tarik wisata di Kabupaten Lahat adalah budaya dan alam. Heritage tourism as embracing both ecotourism and cultural tourism, with an emphasis on conservation and cultural heritage (Pederson, 2002 dalam Southall \& Robinson, 2011: 177). Pengembangan kompleks bangunan megalitik di Lahat sebagai daya tarik wisata budaya dan alam dapat dilaksanakan secara bersamaan. Pengembangan kawasan bangunan megalitik dengan pengelolaan yang menitikberatkan pada pelestarian secara tidak langsung juga menjaga pelestarian lingkungan terutama berbagai flora yang ada di sekitarnya sebagai penyangga. Pengembangan wisata budaya dan alam secara ideal dapat dilaksanakan secara bersamaan untuk mempertahankan identitas lokal serta memberikan pemahaman dan rasa bangga terhadap kebudayaan lokal masyarakat pendukungnya di masa lalu. Undang-undang No. 11 Tahun 2010 pasal 1 butir 22 mendefinisikan pelestarian sebagai upaya dinamis untuk mempertahankan keberadaan Cagar Budaya dan nilainya dengan cara melindungi, mengembangkan, dan memanfaatkannya. Menjaga kondisi lingkungan flora disekitar bangunan megalitik merupakan salah satu upaya untuk perlindungan baik secara fisik maupun kimia.

Pengembangan merupakan suatu proses atau aktivitas untuk memajukan sesuatu yang dianggap perlu melalui peremajaan atau memelihara yang sudah berkembang agar menjadi lebih menarik dan berkembang (Alwi, 2005: 538). Pengembangan pariwisata merupakan suatu upaya membangun sektor pariwisata dengan jalan 
mengintegrasikan segala aspek di luar sektor pariwisata yang berkaitan secara langsung maupun tidak langsung untuk kelangsungan pengembangan pariwisata (Swarbrooke, 1996: 99). Dalam pengembangan pariwisata di Kabupaten Lahat selain memiliki keunikan atraksi wisata, banyak aspek yang sangat terkait seperti aksesibilitas, amenitas, dan kelembagaan terutama terkait regulasi dan kebijakan, serta kepedulian masyarakat di sekitar kawasan bangunan megalitik. Pengembangan wisata budaya dan alam di daerah ini mempunyai beberapa fungsi seperti: a.) meningkatkan perekonomian dengan membuka lebih banyak peluang usaha; b.) melestarikan warisan budaya dan lingkungannya; c.) meningkatkan kebanggaan daerah; e.) memupuk rasa cinta tanah air dan bangsa; dan f). sebagai sarana diplomasi budaya. Untuk menjalankan fungsi tersebut sangat diperlukan koordinasi dan sinkronisasi peran dari masing-masing aktor pariwisata di daerah ini terutama pemerintah daerah Kabupaten Lahat dengan jajarannya, pelaku industri, komunitas, akademisi dan masyarakat dis ekitarnya yang dikenal dengan aktor pentahelix.

Pengembangan kawasan bangunan megalitik sebagai daya tarik wisata budaya dan alam secara bersamaan mempunyai beberapa tujuan yaitu: a.) membangun kompleks bangunan megalitik sebagai atraksi wisata budaya dan alam yang beda fungsi dengan masyarakat pendukungnya di masa lalu, yaitu membangun sistem baru dalam konteks kekinian; b.) meningkatkan jumlah kunjungan wisatawan; c.) meningkatkan fasilitas pariwisata; d.) menciptakan atraksi baru atau meningkatkan keragaman atraksi di daerah Lahat agar waktu tinggal wisatawan lebih lama; e.) pelestarian budaya dan alam; dan f.) meningkatkan pergerakan ekonomi masyarakat dengan berkembangya iklim usaha atau investasi. Dalam pengembangan kawasan bangunan megalitik sebagai atraksi wisata budaya dan alam di Kabupaten Lahat mencakup beberapa komponen yaitu: a.) harus mempunyai daya tarik atau atraksi wisata (attraction) berbasis utama budaya (bangunan megalitik) dan alam (lansekap dataran tinggi, pertanian, permukiman); b.) aksesibilitas (accessibility), yang mencakup dukungan sistem transportasi atau akses menuju destinasi; c.) amenitas (amenities) mencakup fasilitas penunjang dan pendukung wisata yang meliputi: akomodasi, rumah makan, kafe/restoran, retail, toko cinderamata, fasilitas penukaran uang, biro perjalanan, pusat informasi wisata, dan fasilitas kenyamanan lainnya; d.) fasilitas pendukung (ancillary service), yaitu ketersediaan fasilitas pendukung yang digunakan oleh wisatawan, seperti bank, rumah sakit, dan sebagainya; dan e.) kelembagaan (institution), yaitu keterkaitan dengan keberadaan dan peran masing-masing unsur dalam mendukung terlaksananya kegiatan pariwisata termasuk masyarakat setempat sebagai tuan rumah (host). Dalam pengembangan kawasan kompleks bangunan megalitik sebagai komoditas pariwisata, kelima komponen tersebut secara holistik harus sinergi satu sama lainnya dengan tujuan yang sama yaitu menjadikan kawasan ini sebagai daya tarik wisata budaya dan alam dengan menjaga prinsip-prinsip pelestarian. Dalam konteks pelestarian pengembangan kawasan bangunan megalitik sebagai daya tarik wisata harus memperhatikan prinsip kemanfaatan, keamanan, keterawatan, keaslian, serta nilai dan makna budaya yang melekat. Adapun arah pengembangannya adalah untuk memacu pengembangan ekonomi yang hasilnya dapat untuk pemeliharaan warisan budaya itu sendiri dan kesejahtraan masyarakat.

Bangunan megalitik di Lahat sebagai warisan budaya dapat dijadikan sebagai komoditas pariwisata karena mempunyai nilai experiences seperti nilai simbolik, estetika, informatif dan ekonomik yang terkandung didalamnya. Menginformasikan nilai budaya ini kepada wisatawan sangat penting dengan berbagai kemasan sesuai segmen pasar yang dituju. Pengembangan kompleks bangunan megalitik di Kabupaten Lahat sebagai daya tarik wisata agar dapat lebih menarik wisatawan, sangat tergantung bagaimana sumber daya ini dikemas atau menyampaikan nilai experiences kepada wisatawan. Ada beberapa prinsip yang harus diperhatikan dalam pengemasan bangunan megalitik sebagai atraksi wisata yaitu: a.) mempertahankan keasliannya (authenticity) sebagai upaya pelestarian dengan memberikan informasi nilai penting kepada masyarakat luas; b.) kontekstualisasi (contextualization) sebagai upaya pemaknaan kembali dalam konteks kekiniian atau sistem baru dengan tujuan untuk memberi roh baru agar memberikan manfaat bagi masyarakat sekarang, baik untuk ekonomi maupun jati diri, dan c.) interaktivitas (interactivity) agar informasi yang terkandung dalam setiap warisan budaya harus mampu 
tersampaikan dan dipahami oleh masyarakat luas termasuk wisatawan, sehingga wisatawan pun dapat memberikan respon terhadap nilai dan makna budaya yang terkandung. Keautentikan (authenticity) warisan budaya sebagai daya tarik wisata penting agar memberikan kesempatan kepada masyarakat plural atau multicultural untuk menafsirkan nilai dan makna budaya yang terkandung sesuai dengan versi mereka masingmasing.

Produk pariwisata budaya memiliki segmen pasar khusus yaitu para knowledge workers atau dalam istilah kepariwisataan disebut mature tourist atau wisatawan yang berpengalaman. Mereka melakukan perjalanan atau kunjungan ke kawasan lain dengan tujuan tidak hanya bersifat rekreasional tetapi lebih bermotivasi untukmenambah pengetahuan dan pengalaman baru. Segmen pasar pariwisata ini untuk menambah pengetahuan dan pengalaman baru selain mereka mengunjungi destinasi yang mempunyai warisan budaya tangible, juga terlibat langsung dalam aktivitas masyarakat keseharian masyarakat lokal (budaya intangible). Dalam era globalisasi, pengembangan warisan budaya sebagai destinasi wisata di Lahat sangat penting dengan melibatkan masyarakat lokal agar mereka ikut merasakan sebagai pemilik warisan budaya meskipun dengan konteks sosial masyarakat sekarang. Hal ini dengan tujuan agar warisan budaya yang ada di sekitar mereka tidak menjadi sebongkah batu atau benda mati yang tidak mempunyai makna, melainkan berperan penting dalam sistem kehidupan masyarakat sekarang baik untuk penciptaan jati diri atau identitas maupun kesejahtraan masyarakat. Pada beberapa negara maju, warisan budaya dalam bentuk bangunan-bangunan kuno dilestarikan sebagai bagian dari identitas atau jati diri kota dan masyarakat di sekitarnya.

Pengambil kebijakan dalam pengembangan bangunan megalitik sebagai daya tarik wisata di Kabupaten Lahat, juga harus menyadari dan memahami prinsip globalisasi sebagai proses budaya yang kompleks dan bukan hanya suatu proses ekonomi bebas. Pengembangan kompleks bangunan megalitik sebagai daya tarik wisata merupakan suatu upaya untuk melestarikan sekaligus berusaha untuk tetap mempertahankan jati diri daerah dan masyarakat Lahat. Kompleks megalitik ini memiliki keunikan yang tidak dapat ditemukan di tempat lain. Budaya dunia pada era globalisasi ini cenderung homogen dan masyarakat mempunyai kecenderungan untuk melihat dan mengagumi hal-hal yang khas dan unik yang tidak mereka temukan di daerahnya. Hal ini menjadi peluang untuk mengembangkan kawasan komplek bangunan megalitik yang ditemukan di Kabupaten Lahat sebagai daya tarik wisata global. Perubahan besar dalam industri pariwisata pada masyarakat global semakin nyata jika dikaitkan dengan kecenderungan mereka dalam melakukan aktivitas berwisata dalam dasarwarsa terakhir. Perkembangan pariwisata saat ini cenderung untuk meninggalkan perjalanan wisata bersama dalam paket-paket wisata (masstourism) dengan jumlah yang cukup besar dan beralih pada kegiatan pariwisata yang bersifat pribadi dengan jumlah yang sedikit dengan tujuan khusus. Kecenderungan berwisata yang baru (sering disebut ecotourism, alternative tourism, green tourism) mempunyai tujuan untuk mendapat pengalaman unik sambil ikut melestarikan sumber daya wisata yang mereka kunjungi beserta lingkungannya. Dalam konteks kepariwisataan, wisatawan dari negara-negara maju yang hidup dengan segala kecanggihan teknologi dan era globalisasi melakukan perjalanan tidak saja dengan tujuan rekreasi, tetapi lebih untuk mengekplorisasi suasana asli (authentic) untuk mendapatkan pengalaman dan pengetahuan yang baru. Tempat-tempat bersejarah termasuk kompleks bangunan megalitik merupakan salah satu daya tarik wisata bagi wisatawan minat khusus untuk dapat menemukan jati diri mereka yang tidak dapat mereka temukan di dalam kehidupan mereka sehari-hari.

Daya tarik wisata harus terkait dengan empat hal yaitu: a.) keunikan: sebagai kombinasi kelangkaan dan kekhasan yang melekat pada suatu daya tarik wisata; b.) orisinalitas (mencerminkan keaslian atau kemurnian): seberapa jauh suatu produk tidak terkontaminasi atau tidak mengadopsi nilai yang berbeda dengan nilai aslinya; c.) otentisitas, mengacu pada keaslian yang lebih sering dikaitkan dengan keantikan atau eksotisme budaya sebagai daya tarik wisata dan merupakan kategori nilai yang memadukan sifat alamiah, eksotis, dan bersahaja; dan d.) eksotis, orisinalitas lebih menekankan pada keaslian (Damanik \& Weber, 2006: 13). Kompleks bangunan megalitik yang ditemukan di Kabupaten Lahat memiliki keempat kategori tersebut yaitu unik, asli, otentik, dan eksotis sehingga sangat potensial dikembangkan sebagai 
daya tarik wisata secara global. Peluang lain kompleks bangunan ini sebagai daya tarik wisata budaya dan alam yaitu beragamnya jenis temuan

dengan distribusi sebaran (tabel 1) pada lokasi (lansekap) yang berbeda sehingga meningkatkan keragaman atraksi wisata.

Tabel 1. Kompleks Bangunan Megalitik yang ada di Kabupaten Lahat, Provinsi Sumatera Selatan

\begin{tabular}{|c|c|c|c|c|c|c|}
\hline No & $\begin{array}{l}\text { Kode } \\
\text { Situs }\end{array}$ & Nama Situs & Jenis Temuan & Periode & Desa/Kelurahan & Kecamatan \\
\hline 1 & TH1 & Tinggihari I & $\begin{array}{l}\text { Menhir berelief } 1 \text { buah, Arca } \\
\text { Megalitik } 2 \text { bh, Lumpang batu } 4 \\
\text { buah, Batu Datar } 1 \text { buah, lesung } \\
\text { batu } 1 \text { buah. }\end{array}$ & Prasejarah & Tinggi Hari & Gumay Ulu \\
\hline 2 & TH2 & Tinggihari II & $\begin{array}{l}\text { Arca Megalitik, Menhir, Tetralith, } \\
\text { Lumpang batu. }\end{array}$ & Prasejarah & Tinggi Hari & Gumay Ulu \\
\hline 3 & TH3 & Tinggihari III & $\begin{array}{l}\text { Arca Megalitik, Menhir berelief, } \\
\text { Monolith, Batu datar, Tetralith. }\end{array}$ & Prasejarah & Tinggi Hari & Gumay Ulu \\
\hline 4 & TH4 & Tinggihari IV & $\begin{array}{l}\text { Arca Megalitik, Tetralith, Monolith, } \\
\text { Batu datar, Lumpang batu. }\end{array}$ & Prasejarah & Tinggi Hari & Gumay Ulu \\
\hline 5 & THR & Tinggihari & Kepala Arca & Prasejarah & Tinggi Hari & Gumay Ulu \\
\hline 6 & TTL & Tanjung Telang & Arca Megalitik, Menhir, Batu Datar & prasejarah & Tanjung Telang & $\begin{array}{l}\text { Merapi } \\
\text { Barat }\end{array}$ \\
\hline 7 & $\mathrm{RDH}$ & Rinduhati & Arca Megalitik, Tetralith & Prasejarah & Rindu Hati & Gumay Ulu \\
\hline 8 & MDA & Muaradua & $\begin{array}{l}\text { Arca Megalitik, Dolmen, Lumpang } \\
\text { batu }\end{array}$ & Prasejarah & Muaradua & Gumay Ulu \\
\hline 9 & GMG & Gunung Megang & $\begin{array}{l}\text { Bilik Batu, Arca Megalitik, Dolmen, } \\
\text { Lumpang batu. }\end{array}$ & Prasejarah & Gunung Megang & Jarai \\
\hline 10 & PJB & Pajar Bulan & $\begin{array}{l}\text { Batu Bergores, Dolmen, Tetralith, } \\
\text { Lumpang batu, Batu Datar }\end{array}$ & Prasejarah & Pajar Bulan & Pajar Bulan \\
\hline 11 & MTW & Muara Tawi & Dolmen, Lesung batu, Lumpang batu & Prasejarah & Muara Tawi & Jarai \\
\hline 12 & PGD & Pagar Dewa & $\begin{array}{l}\text { Batu temu gelang (Stone enclosure), } \\
\text { Umpak rumah, Dolmen, Monolith, } \\
\text { Batu Datar, Tetralith. }\end{array}$ & Prasejarah & Pagar Dewa & Jarai \\
\hline 13 & SMR & Sumur & $\begin{array}{l}\text { Dolmen, Batu Datar, Lumpang batu, } \\
\text { Tetralith. }\end{array}$ & Prasejarah & Sumur & Pajar Bulan \\
\hline 14 & JMR & Jemaring & $\begin{array}{l}\text { Dolmen, Batu datar, Lumpang Batu, } \\
\text { Tetralith, Batu gelang }\end{array}$ & Prasejarah & Jemaring & Jarai \\
\hline 15 & TJS & Tanjungsirih & $\begin{array}{l}\text { Lumpang batu berlubang } 4 \text { buah, } \\
\text { Arca Megalith, kursi batu, batu datar }\end{array}$ & Prasejarah & Tanjungsirih & $\begin{array}{l}\text { Pulau } \\
\text { Pinang }\end{array}$ \\
\hline 16 & $\mathrm{MDU}$ & Muaradanau & Arca Megalitik, Monolith & Prasejarah & Muara Danau & $\begin{array}{l}\text { Pulau } \\
\text { Pinang }\end{array}$ \\
\hline 17 & SJB & Sinjarbulan & Arca Megalitik 6 buah & Prasejarah & Sinjar Bulan & Gumay Ulu \\
\hline 18 & TPA & $\begin{array}{l}\text { Talang } \\
\text { Pagaragung }\end{array}$ & Bilik Batu, Kepala Arca & Prasejarah & $\begin{array}{l}\text { Talang Pagar } \\
\text { Agung }\end{array}$ & Pajar Bulan \\
\hline 19 & PPG & Pulaupanggung & $\begin{array}{l}\text { Lumpang batu berelief, Arca } \\
\text { Megalitik, Lumpang batu. }\end{array}$ & Prasejarah & Pulau Panggung & Pajar Bulan \\
\hline 20 & GKY & Gunungkaya & $\begin{array}{l}\text { lumpang batu, lesung batu, dolmen, } \\
\text { tetralith, menhir, tempayan kubur, } \\
\text { arca batu, serta bilik batu. }\end{array}$ & Prasejarah & Gunung Kaya & Jarai \\
\hline 21 & TJB & Tanjungberingin & Arca Megalitik 1 buah & Prasejarah & Tanjung Beringin & Kota Agung \\
\hline 22 & GRM & Geramat & Arca Megalitik, Monolith, Dakon & Prasejarah & Geramat & Mulak Ulu \\
\hline 23 & KRL & Kotaraya Lembak & $\begin{array}{l}\text { Bilik batu, Tetralith, Dolmen, batu } \\
\text { datar, Menhir, Lumpang batu. }\end{array}$ & Prasejarah & $\begin{array}{l}\text { Kota Raya } \\
\text { Lembak }\end{array}$ & Pajar Bulan \\
\hline 24 & PAG & Pagargunung & $\begin{array}{l}\text { Arca Megalitik, Menhir, Lumpang } \\
\text { batu }\end{array}$ & Prasejarah & Pagaralam & $\begin{array}{l}\text { Pagar } \\
\text { Gunung }\end{array}$ \\
\hline
\end{tabular}




\begin{tabular}{llllll}
\hline 25 & TJR & Tanjung Raja & Arca Megalitik, Tetralith, Menhir & Prasejarah & Tanjung Raja \\
\hline 26 & KBP & Kantor Bupati & Arca Megalitik, Meriam Kolonial & $\begin{array}{l}\text { Prasejarah, } \\
\text { Sejarah }\end{array}$ & Bandar Jaya \\
\hline 27 & MRA & Makam Raja Api & $\begin{array}{l}\text { Makam, Arca Megalitik, Monolith, } \\
\text { Batu Datar, Dolmen. }\end{array}$ & $\begin{array}{l}\text { Sejarah, } \\
\text { Prasejarah }\end{array}$ & Lahat Tengah \\
\hline 28 & BYK & Balai Yasa PT. KAI & $\begin{array}{l}\text { Bangunan Kolonial, kereta Api, } \\
\text { Tower Air }\end{array}$ & Sejarah & Bedeng \\
\hline
\end{tabular}

Sumber: Pemda Kab. Lahat, 2012: 39

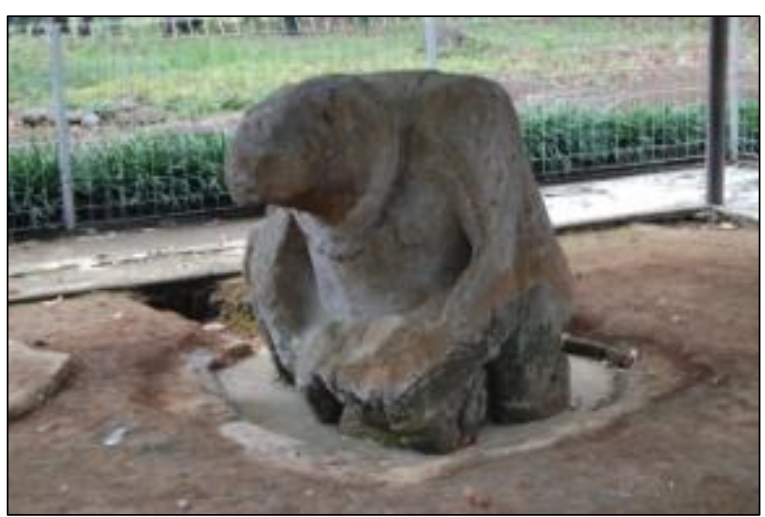

Gambar 1. Arca Megalitik situs Gunung Megang (Sumber: Pemda Kab. Lahat, 2012)

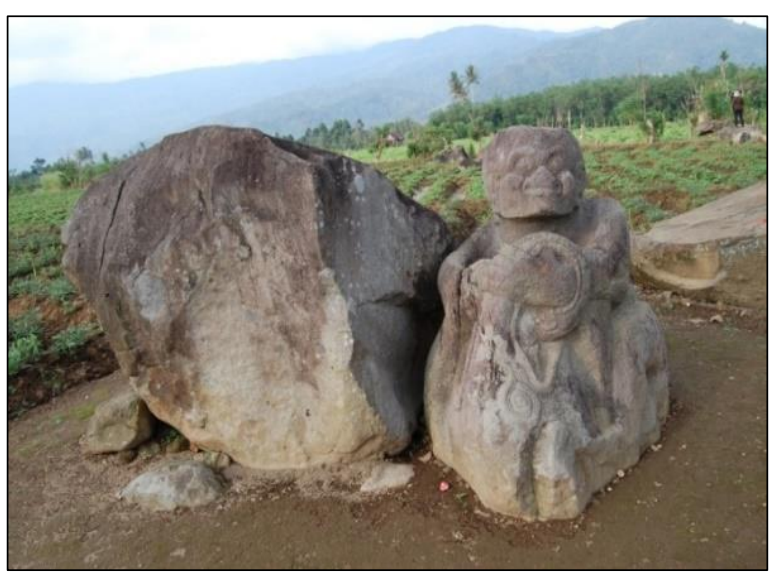

Gambar 2. Arca Megalitik 1 situs Tinggihari I (Sumber: Pemda Kab. Lahat, 2012: 42)

Keunikan dari bangunan megalitik sebagai daya tarik wisata di daerah ini karena sangat langka dan mempunyai kekhasan tersendiri. Temuan arca-arca megalitik yang tersebar di beberapa daerah dengan lansekap yang khas di Lahat sulit ditemukan di daerah atau negara lain. Kompleks arca-arca megalitik yang ditemukan di kawasan ini mempunyai jumlah yang cukup banyak dan terdistribusi secara luas baik dipermukiman penduduk maupun di area pertanian. Arca-arca ini juga mempunyai motif hias dan memiliki ornamen yang sangat unik dan khas juga ditemukan berbeda satu dengan yang lain. Bangunan megalitik yang ditemukan di kawasan ini juga mempunyai tingkat orisinalitas yang tinggi karena masih mencerminkan keaslian baik dari segi bahan dan teknologi pengerjaan. Lokasi ditemukannya sejumlah bangunan megalitik saat ini diperkirakan sudah mengalami transformasi terutama karena faktor alam seperti banjir.

Nilai experiences warisan budaya di Kabupaten Lahat ini masih tinggi sehingga masyarakat luas termasuk wisatawan masih memiliki kesempatan untuk memberikan persepsi dan interprestasi sendiri sesuai dengan tingkat pemahaman mereka. Keunikan dan keaslian bangunan megalitik di Kabupaten Lahat juga menunjukan eksotisme budaya yang tinggi yang dipadukan dengan morfologi lingkungan dan landscape disekitarnya. Nilai budaya dan keunikan warisan budaya ini dapat menciptakan daya tarik wisata budaya dan alam serta dapat menjadi motivasi penarik bagi wisatawan. Faktorfaktor ini menjadi daya tarik bagi wisatawan khususnya yang tertarik pada wisatawan minat khusus baik wisata budaya maupun alam.

Tingkat pengembangan kawasan bangunan megalitik di daerah Lahat sebagai daya tarik wisata sangat bervariasi karena antar daerah satu dengan yang lain mempunyai kondisi berbeda, seperti: a.) ada kawasan yang awalnya belum dimanfaatkan sebagai daya tarik wisata sehingga diperlukan pengembangan secara keseluruhan; $b$.) menambahkan daya tarik pada kawasan situs yang sudah pernah digunakan sebagai destinasi wisata (sudah sering dikunjungi wisatawan); c.) membangun atraksi untuk meningkatkan kunjungandengan segmen pasar yang lebih luas; d.) meningkatkan fasilitas pengunjung dengan tujuan agar wisatawan dapat lebih lama tinggal dengan pengeluaran mereka lebih besar; dan e.) menciptakan atraksi baru yang mempunyai pola keterkaitan antara kawasan satu dengan yang lain di daerah Lahat. 


\section{Strategi Pengelolaan Kawasan Bangunan Megalitik sebagai Daya TarikWisata}

Strategi merupakan suatu proses penentuan nilai yang penting dan pembuat keputusan dalam pemanfaatan sumber daya yang menimbulkan suatu komitmen bagi organisasi yang bersangkutan kepada tindakan-tindakan yang mengarah pada masa depan (Marpaung, 2001: 52). Strategi juga dapat sebagai alat untuk mencapai tujuan perusahaan dalam jangka panjang, program tindak lanjut serta prioritas alokasi sumber daya (Chandler dalam Rangkuti, 2002: 3). Dari beberapa konsep di atas, strategi pengelolaan kawasan bangunan megalitik sebagai daya tarik wisata di Kabupaten Lahat merupakan suatu keputusan untuk memanfaatkan sumber daya budaya dan alam dengan menyusun berbagai rencana yang komprehensif dan terpadu dari berbagai stakeholder untuk mencapai tujuan agar menjadi daya tarik wisata yang banyak dikunjungi wisatawan. Sementara itu, pengelolaan atau manajemen berarti kemampuan dan ketrampilan khusus untuk melakukan sesuatu kegiatan baik bersama orang lain maupun melalui orang lain dalam mencapai tujuan organisasi (Sudjana, 2000: 17). Pengelolaan atau manajemen juga merujuk kepada seperangkat peranan yang dilakukan oleh seseorang atau sekelompok orang, atau juga bisa merujuk kepada fungsi-fungsi yang melekat pada peran tersebut. Ahli manajemen mengemukakan sudut pandang yang hampir sama mengenai urutan fungsi manajemen, yaitu planning (perencanaan), directing (mengarahkan), organizing (termasuk coordinating), dan controlling (pengawasan) (Leiper dalam Pitana \& Surya, 2009: 80). Strategi pengelolaan kawasan bangunan megalitik tentunya harus mengarah pada pembangunan pariwisata dengan tujuan pelestarian sumber daya, agar dapat menerapkan konsep pembangunan yang berkelanjutan. Pelestarian sumber daya budaya dan lingkungan alam merupakan tujuan utama dalam pengembangan pariwisata di daerah Lahat, sekaligus memberikan kesejahtraan bagi masyarakat sekitarnya pada masa sekarang dan yang akan datang. Dalam bagian ketentuan umum Undang-undang No. 11 tahun 2010 tentang Cagar Budaya, dijelaskan bahwa yang dimaksud dengan pelestarian adalah upaya dinamis untuk mempertahankan keberadaan cagar budaya dan nilainya dengan cara melindungi, mengembangkan, dan memanfaatkannya. Rumusan ini menegaskan bahwa pengelolaan dalam pemanfaatan kompleks bangunan megalitik sebagai daya tarik wisata merupakan salah satu usaha untuk pelestariannya. Secara internal, kompleks bangunan megalitik di Kabupaten Lahat mempunyai potensi besar untuk dikembangkan sebagai daya tarik wisata budaya dan alam, karena mempunyai berbagai nilai dan makna yang dapat memberikan experiences berupa: 1) nilai penting sejarah: berkaitan erat dengan pristiwa sejarah daerah Lahat, sebagai media dalam membantu upaya masyarakat untuk mengenal dan merevitalisasikan identitas sosial budaya, dan menjadi bukti beragam fase dan peristiwa penting sejarah kehidupan masyarakat; 2) nilai informasi: terkait peristiwa yang terjadi di masa lalu, proses perubahan budaya dan adaptasi manusia terhadap lingkungannya, tindakan manusia dan interaksi manusia dengan manusia lainnya, dan menjawab masalah yang berkaitan dengan pengembangan metode, teknik, dan teori dalam berbagai bidang ilmu; 3) nilai estetika: terkait dengan seni rupa, seni hias, seni bangunan, seni pahat maupun bentuk-bentuk kesenian lainnya serta menjadi ilham untuk menghasilkan karya-karya budaya di masa kini dan akan datang; dan 4) nilai simbolik: memberikan pemahaman latar belakang kehidupan sosial, sistem kepercayaan, dan mitologi yang semuanya merupakan bagian dari jati diri daerah dan masyarakat daerah Lahat.

Pengelolaan kawasan ini sebagai daya tarik wisata juga mempunyai nilai tambah karena secara otomatis juga melestarikan lingkungan ekologis atau lansekap yang ada di sekitarnya, menjadi kebanggaan dan identitas daerah, serta sebagai alat diplomasi daerah dengan daerah atau negara lain. Potensi ini juga secara eksternal penting sebagai: a.) objek penelitian (scientific research); b.) sumber inspirasi karya seni atau penciptaan souvenir (creative arts); c.) media pendidikan bagi generasi muda; d.) banyak diminati wisatawan; e.) meningkatkan solidaritas dan integrasi antar komunitas masyarakat; dan f.) sebagai pusat bisnis/ekonomi masyarakat. Dalam pengelolaan kawasan bangunan megalitik sebagai daya tarik wisata, meskipun mempunyai banyak kekuatan dan peluang sebagai daya tarik wisata ternyata juga mempunyai kelemahan yang harus segera diminimalisasi.

Strategi dalam pengelolaan kawasan kompleks bangunan megalitik sebagai kawasan wisata budaya dan alam selain memiliki atraksi wisata yang menarik juga harus didukung oleh 
berbagai faktor lainnya. Ketersediaan dan kesiapan aksesibilitas, amenitas dan pemberdayaan masyarakat sekitar merupakan faktor penting dalam pengelolaan. Aksesibilitas untuk mencapai kawasan bangunan megalitik di Lahat yang mempunyai potensi sebagai daya tarik wisata budaya dan alam masih kurang. Aksesibilitas baik dari sektor jasa (informasi), jaringan infrastruktur maupun moda transportasi di daerah ini masih sangat kurang, termasuk rambu-rambu untuk menuju atraksi wisata. Begitu juga dengan ketersediaan amenitas atau akomodasi lainnya secara kualitas dan kuantitas kurang. Untuk pelestarian dan keberlanjutan kawasan megalitik ini sebagai daya tarik wisata, maka pemberdayaan masyarakat lokal sangat penting. Untuk meningkatkan ketersediaan dan kesiapan, maka sinergisitas antar stakeholder terkait sangat penting. Mengemas potensi budaya dan alam di daerah ini sebagai atraksi wisata dengan melengkapi berbagai fasilitas pendukung dengan tujuan untuk melindungi warisan budaya dari berbagai dampak negatif yang ditimbulkan karena aktivitas pariwisata. Kesiapan dan ketersediaan faktor-faktor ini juga penting untuk memberikan kepuasan kepada wisatawan.

Pengelolaan kompleks bangunan megalitik di Lahat sebagai daya tarik wisata seperti pisau bermata dua. Aktivitas pariwisata akan dapat melestarikan pusaka budaya tersebut, namun di sisi lain pariwisata juga dapat merusak atau berdampak negatif terhadap pusaka budaya tersebut (Ardika, 2007: 18). Untuk meningkatkan warisan budaya sebagai daya tarik wisata dan meminimalisasi dampak negatif tersebut, diperlukan strategi yang tepat. Menggunakan pendekatan produk dan pemasaran yang berimbang dengan memadukan antara pelestarian dan pengelolaan warisan budaya dan alam sebagai sebuah komoditas pariwisata. Pendekatan ini harus memberikan keseimbangan antara prinsip pengelolaan warisan budaya yang lebih cenderung untuk memprioritaskan pelestarian selain pemanfaatannya sebagai daya tarik wisata. Warisan budaya sebagai komoditas pariwisata lebih cenderung untuk mendatangkan wisatawan sebanyak-banyaknya. Di satu sisi bangunan megalitik di kawasan ini harus dilestarikan karena merupakan sumber daya yang tidak dapat diperbaharui (unrenewable resources). Untuk itu pengelola harus dengan bijaksana dalam mengemas daya tarik wisata agar tidak semata mata sebagai komoditas pariwisata. Aktivitas wisata tidak saja terfokus pada sumber daya budaya, tetapi tetapi dikemas dalam satu paket dengan lansekap dan atraksi wisata lain yang ada di sekitarnya. Kompleks bangunan megalitik sebagai sumber daya dalam industri pariwisata sangat kompleks dan multi sektor, sehingga strategi dalam pengelolaanya juga harus melibatkan berbagai sektor. Hal ini penting dilakukan agar sumber daya ini terus mempunyai makna dalam setiap generasi, dan bukan menjadi seonggok bongkahan batu yang tanpa makna dan nilai. Budaya tidak dapat dihentikan dan secara konstan selalu berkembang, dibangun, serta diciptakan kembali untuk menjawab tantangan zaman dan perkembangan kebutuhan (Geertz , 1997: 19). Dengan strategi yang tepat, kawasan komplek bangunan megalitik di Kabupaten Lahat dapat lebih berkembang dalam konteks kekinian untuk menjawab kebutuhan dan tuntutan sosial budaya masyarakat sekarang.

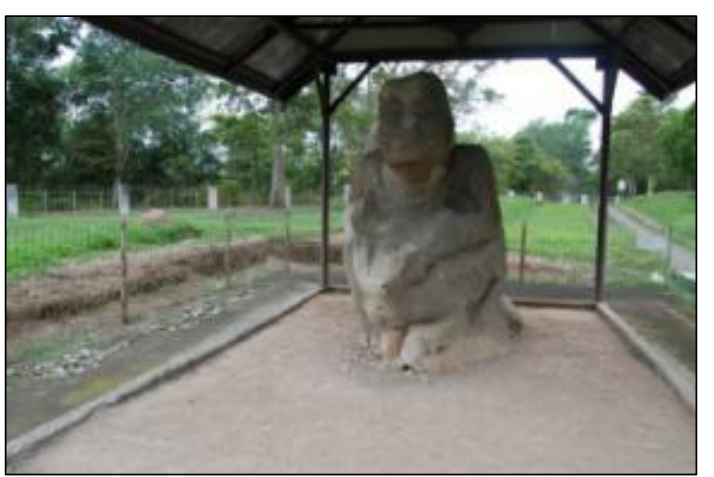

Gambar 3. Arca Megalitik 1 situs Tinggihari III (Sumber: Pemda Kab. Lahat, 2012: 51)

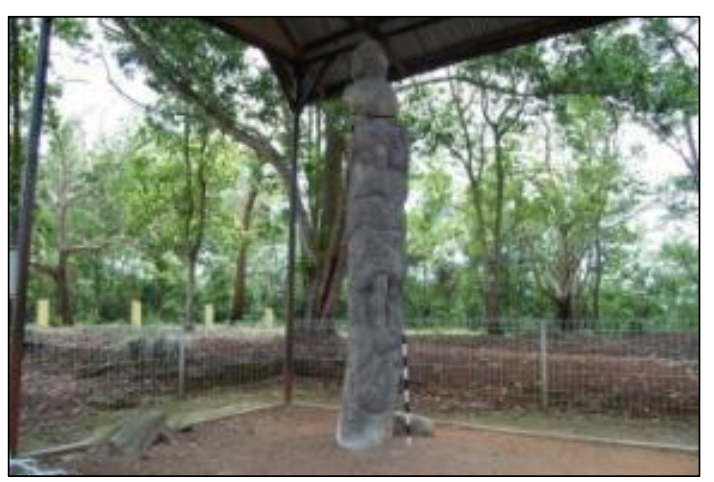

Gambar 4. Menhir Berelief situs Tinggihari I (Sumber: Pemda Kab. Lahat, 2012: 42)

Dalam perspektif budaya, aktivitas kepariwisataan merangsang tumbuh kembangnya kreasi seni budaya yang dapat diperkenalkan kepada para wisatawan. Untuk itu, perlu digali kebudayaan daerah (lokal), dikembangkan, bahkan dilestarikan (Munawaroh, 2001: 93-94). 
Untuk menjaga pelestarian kompleks bangunan megalitik sebagai daya tarik wisata, maka kebudayaan sebagai produk pariwisata budaya yang dikonsumsi oleh wisatawan adalah aspek ekstrinsiknya. Pada saat ada kunjungan wisatawan, aspek ini ditambahkan unsur-unsur experiences sebagaimana sebuah asset budaya yang dikemas sebagai komoditas untuk konsumen. Salah satu perbedaan antara warisan budaya sebagai industri budaya dan sektor pariwisata adalah pariwisata digerakkan oleh pasar industri dan lebih menekankan pada tujuan kemudahan untuk konsumen atau permintaan, sementara industri budaya menekankan pada produk dan aspek penawaran (Ap \& Mark, 1999: 5). Strategi pengelola di kawasan ini harus dapat menawarkan produk dengan berbagai penawaran dengan aspek ekstrinsiknya yang menekankan pada aspek nilai dan makna budaya yang dikandungnya dalam setiap penawaran kepada wisatawan. Strategi ini dilakukan agar mendapatkan titik temu yang ideal dan tercapai keseimbangan untuk meminimalisasi perbedaan antara tujuan pelestarian budaya dan industri pariwisata. Strategi dalam pengelolaan warisan budaya sebagai daya tarik wisata juga harus mampu: a.) meningkatkan citra Kabupaten Lahat untuk mendorong datang dan berkembangnya investor; b.) meningkatkan kuantitas dan kualitas dari fasilitas dan infrastruktur di sekitar destinasi; c.) memberikan kebanggaan bagi masyarakat Lahat karena banyak dikunjungi wisatawan; dan d.) membuka peluang usaha dan lapangan pekerjaan baru untuk meningkatkan pergerakan ekonomi masyarakat.

Strategi lainnya agar wisatawan lebih mengekplorasi secara mendalam potensi kawasan bangunan megalitik di kawasan ini, yaitu perlu dikembangkan paket wisata berbasis program terutama untuk wisatawan yang mempunyai minat khusus. Wisatawan minat khusus umumnya mempunyai tipe well educated (Fletcher, 1997: 136), sehingga perlu dirancang program paket wisata sampai pada wisatawan melakukan interaksi dengan masyarakat atau stakeholder terkait dengan keberadaan warisan budaya di daerah ini. Pengelola harus tetap menjaga orisinalitas dan otentisitas bangunan megalitik untuk memuaskan wisatawan dengan tujuan ekonomi, tetapi tetap mempertahankan keaslian dan keotentikannya. Untuk tujuan ekonomi, industri pariwisata dapat membantu menaikkan standar hidup masyarakat dengan keuntungan ekonomi yang didapat dari pengelolaan kompleks bangunan megalitik sebagai daya tarik wisata. Pengembangan infrastruktur dan penyediaan fasilitas wisata juga dapat memberikan keuntungan bagi wisatawan maupun masyarakat lokal. Strategi untuk pengembangan kawasan bangunan megalitik di Lahat harus meningkatkan peran aktor stakeholder pentahelix pariwisata yaitu: 1) akademisi berperan menyediakan Sumber Daya Manusia pariwisata professional sesuai kebutuhan sosial dan bisnis/industri dan karakter daya tarik serta sosial masyarakat lokal; 2) Bisnis: menciptakan pasar, jasa, serta lapangan pekerjaan serta membentuk komunitas dan entrepreneur pariwisata; 3) Komunitas: terlibat dalam perencanaan, pengelolaan, pengambilan keputusan, dan evaluasi pembangunan pariwisata serta menggali dan melestarikan kepariwisataan dengan mengembangkan budaya lokal dan lingkungan alam; 4) Pemerintah: membuat kebijakan dan regulasi terkait kepariwisataan, sebagai fasilitator, menciptakan iklim usaha yang kondusif, melestarikan sumber daya pariwisata sebagai asset nasional, dan mendorong investor; dan 5) Media: menyediakan informasi kepariwisataan, melaksanakan promosi pariwisata, dan melaksanakan mekanisme check and balance antar actor/stakeholder dalam aktivitas pariwisata.

Bangunan megalitik merupakan jejak-jejak budaya dari jaman megalitik, yang memiliki nilai seni dan budaya khas dari masa itu. Jejak budaya harus dikelola sebagaimana sumber daya lainnya agar terus mempunyai peran dalam kehidupan sosial masyarakat. Pengelolaan kawasan bangunan megalitik sebagai daya tarik wisata budaya dan alam di Lahat juga harus menerapkan konsep pembangunan berkelanjutan. Kebermanfaatan warisan budaya ini harus mampu berlanjut untuk generasi-generasi berikutnya dan tidak berhenti pada masyarakat sekarang. Strategi yang diterapkan dalam pengelolaan kawasan bangunan megalitik sebagai daya tarik wisata yaitu dapat memadukan atau menyelaraskan warisan budaya dan lingkungan alam sekitarnya, meningkatkan peran masyarakat dan aktor pentahelix lainnya, mempertahankan orisinalitas dan otentisitas bangunan megalitik dan lingkungannya, serta menumbuhkan iklim investasi dan usaha masyarakat. Keberlanjutan pariwisata berbasis lingkungan (environmentally sustainable), dapat diterima oleh lingkungan sosial dan budaya masyarakat setempat (socially 
and culturally acceptable), layak dan menguntungkan secara ekonomi (economically viable), dan memanfaatkan teknologi yang layak/pantas untuk diterapkan di wilayah lingkungan tersebut (technologically appropriate) (Sunaryo, 2013: 45). Dalam paparan Dubes Makmur Widodo pada Konfrensi Tingkat Tinggi (KTT) Dunia Pembangunan Berkelanjutan, terdapat 4 (empat) indikator yang dikembangkan pemerintah Republik Indonesia tentang pembangunan pariwisata berkelanjutan menurut Agenda 21 tahun 2000. Keempat indikator tersebut antara lain: 1) Kesadaran tentang tanggung jawab terhadap lingkungan, bahwa strategi pembangunan pariwisata berkelanjutan harus menempatkan pariwisata sebagai green industry atau industri yang ramah lingkungan, yang menjadi tanggung jawab pemerintah, industri pariwisata, masyarakat dan wisatawan;2) Peningkatan peran pemerintah daerah dalam pembangunan pariwisata; 3). Kemantapan/ keberdayaan industri pariwisata yaitu mampu menciptakan produk pariwisata yang bisa bersaing secara internasional; dan 4). Mensejahterakan masyarakat di tempat tujuan wisata.

\section{KESIMPULAN}

Kompleks kawasan bangunan megalitik yang ditemukan di Kabupaten Lahat merupakan jejak-jejak budaya masyarakat dari masa prasejarah yang menunjukkan budaya masyarakat yang pernah berkembang di daerah ini. Keunikan budaya megalitik dalam lansekap alam yang orisinal dapat dikelola menjadi daya tarik wisata sebagai salah satu usaha untuk memberdayakan warisan budaya seperti sumber daya lainnya dalam pembangunan. Perkembangan pariwisata global sangat mempengaruhi pembangunan di segala sektor baik ekonomi, sosial budaya, politik maupun pembangunan infrastuktur. Dalam konteks sistem masyarakat sekarang, kompleks bangunan megalitik mempunyai peluang dan daya saing dalam pembangunan pariwisata global karena dapat memberikan pengalaman dan pengetahuan baru kepada wisatawan. Kawasan ini dapat menjadi daya tarik wisata yang baik karena memilik: keunikan, orisinalitas, otentisitas, dan orisinalitas yang tinggi sehingga wisatawan masih medapatkan pemahaman yang utuh sesuai dengan persepsi dan pengetahuan mereka. Dalam konteks masyarakat sekarang, pembangunan pariwisata dengan menjadikan bangunan megalitik sebagai daya tarik wisata mempunyai beberapa fungsi yaitu: a.) meningkatkan perekonomian dengan membuka lebih banyak peluang usaha; b.) melestarikan warisan budaya dan lingkungannya; c.) meningkatkan kebanggaan daerah; e.) memupuk rasa cinta tanah air dan bangsa; dan f.) sebagai sarana diplomasi budaya. Untuk menjalankan fungsi tersebut, sangat diperlukan koordinasi dan sinkronisasi peran dari masingmasing aktor pariwisata (pentahelix) agar tujuan pembangunan pariwisata di Kabupaten Lahat dapat tercapai.

Kompleks bangunan megalitik di Lahat sebagai daya tarik wisata mempunyai tujuan: a.) membangun kompleks bangunan megalitik sebagai atraksi wisata budaya dan alam yang beda fungsi dengan masyarakat pendukungnya di masa lalu, yaitu masyarakat pendukung budaya megalitik pada masa itu lebih banyak memanfaatkannya dalam aktivitas religi, sementara sekarang lebih dikaitkan dengan ekonomi dan identitas daerah); b.) meningkatkan jumlah kunjungan wisatawan; c.) meningkatkan fasilitas pariwisata; d.) menciptakan atraksi baru atau meningkatkan keragaman atraksi di daerah Lahat agar waktu tinggal wisatawan lebih lama; e.) pelestarian budaya dan alam; dan f.) meningkatkan pergerakan ekonomi masyarakat dengan berkembangya iklim usaha atau investasi. Strategi untuk pencapaian tujuan dan fungsi pengembangan bangunan megalitik sebagai daya tarik wisata mengarah pada pelestarian sumber daya budaya dan alam sehingga konsep pembangunan yang berkelanjutan juga dapat diterapkan dalam pembangunan pariwisata di daerah ini. Strategi pengelolaan pariwisata di daerah ini diharapkan menggunakan pendekatan produk dan pemasaran yang berimbang dengan memadukan antara pelestarian serta pengelolaan warisan budaya dan alam sebagai sebuah komoditas pariwisata.

\section{Ucapan Terima Kasih}

Penulis mengucapkan terima kasih kepada seluruh pihak yang turut membantu penyusunan tulisan ini, serta terima kasih kepada Kapata Arkeologi yang sudah mempublikasikannya. 


\section{DAFTAR PUSTAKA}

Alwi, H. (2005). Kamus Besar Bahasa Indonesia. Jakarta: Departemen Pendidikan Nasional dan Balai Pustaka.

Ap, J., \& Mark, B. (1999). Balancing Cultural Heritage, Conservation and Tourism Development in a Sustainable Manner. In International Conference: Heritage and Tourism. Hong Kong.

Ardika. (2007). Pusaka Budaya dan Pariwisata. Denpasar: Pustaka Larasan.

Astiti, A. (2012). Warisan Budaya dan Profil Kabupaten Lahat. In Sumber Daya Arkeologi dalam Pembangunan Kabupaten Lahat. Lahat: Dinas Kebudayaan dan Pariwisata Kabupaten Lahat.

Crowther, D. (1991). Archaeology, Material Culture and Museum. In Pearce, M. S. (Ed.), Museum Studies in Material Culture (pp. 35-46). Washington DC: Leicester University Press.

Damanik, J., \& Weber, H. F. (2006). Perencanaan Ekowisata: dari Teori ke Aplikasi. Yogyakarta: Andi.

Davidson. (1997). Strategic Marketing Mix, $5^{\text {th }}$ Edition. The Mc Graw Hill Companies, Inc.

Fletcher, J. (1997). Heritage Tourism: Enhancing the Net Benefits of Tourism. In Wiendu, N. (Ed.), Tourism and Heritage Management (pp. 134146). Yogyakarta: Gadjah Mada University Press.

Geertz, C. (1997). Cultural Tourism: Tradition, Identity and Heritage Construction. In Wiendu, N. (Ed.), Tourism and Heritage Management (pp. 14-24). Yogyakarta: Gadjah Mada University Press.

Gunn, C. A. (1998). Tourism Planning. 2nd Edition. New York: Taylor and Francis.

Inskeep, E. (1991). Tourism Planning - An Integrated Sustainable Approach. New York: Van Nostrand Reinhold.

Kingery, W. (1996). Material Science and Material Culture. In Kingery, W. D. (Ed.), Learning From Things, Method and Theory of Material Culture Studies (pp. 181-203). Washington and London: Smitsonian Institution Press.

Lipe, W. (1989). Value and Meaning in Cultural resources. In Cleere, H. (Ed.), Approaches to the Archaelogical Heritage. New York: Cambridge University Press.

Marpaung. H. (2001). Pengetahuan Kepariwisataan. Bandung: Alfabeta.

Munawaroh, S. (2001). Masyarakat Using di Banyuwangi: Studi tentang Kehidupan SosialBudaya. Jantra, I(2), 93-94.

Rangkuti, F. (2002). Measuring Customer Satisfaction Teknik Mengukur dan Strategi Meningkatkan Kepuasan Pelanggan dan Analisis Kasus PLN$J P$. Jakarta: PT. Gramedia Pustaka Utama.
Southall \& Robinson. (2011). Heritage Tourism. In Robinson, P., Heitmann, S., Dieke, P. (Ed.) Research Theme for Tourism (pp. 177-185). CAB International: Library of Congress Cataloging in Publication Data.

Sudjana. (2000). Strategi Pembelajaran. Bandung: Falah Production.

Sunaryo, B. (2013). Kebijakan Pembangunan Destinasi Pariwisata: Konsep dan aplikasinya di Indonesia. Yogyakarta: Gava Media.

Pemda Kab. Lahat. (2012). Laporan Hasil Penelitian dan Pengembangan Informasi Sebaran Potensi Sumber Daya Arkeologi: sebagai asset budaya lokal daerah Kabupaten Lahat Prov. Sumatra Selatan. Lahat: Pemda Kabupaten Lahat.

Pendit, N. S. (1986). Ilmu Pariwisata sebagai Pengantar Perdana. Jakarta: Pradnya Pariwisata.

Pitana, \& Surya. (2009). Pengantar Ilmu Pariwisata. Yogyakarta: Penerbit Andi.

United Nation - World Tourism Organization. (2005). Tourism Highlight 2005. Madrid: UNWTO.an dan Pengembangan Pariwisata. Jakarta. PT. Pradaya Paramita.

Utama, R. (2011). Refleksi Pembangunan Pariwisata Bali: Antara Pelestarian Budaya dan Pembangunan Ekonomi. Retrieved July 10, 2017, from https://tourismbali.wordpress.com/

Yoeti, A. (2002). Perencana Undang-undang RI. UU tentang Cagar Budaya Pub. L. No. 11 (2010). 